\title{
SPME-GCMS Combined AMDIS and KOVÁTS Retention Index to Analyze the Volatile Organic Compounds in Russula rubra (Krombh.) Bres. Essential Oil
}

\author{
Chao Zhao, ${ }^{\mathrm{a}, \mathrm{b}}$ Wenxuan Quan, ${ }^{\mathrm{a}, \mathrm{b}}$ and Guijie Ding ${ }^{\mathrm{a}, \mathrm{b}, *}$ \\ Volatile components in Russula rubra (Krombh.) Bres. were determined \\ with the use of a solid-phase microextraction (SPME)/gas \\ chromatography-mass spectrometry (GC-MS) method. The compounds \\ were identified by the automatic mass spectral deconvolution and \\ identification system (AMDIS) and Kováts retention index (RI). Under the \\ optimized conditions of GC-MS, 52 volatile components were identified \\ in Russula rubra, with the relative percentage accounting for $80.2 \%$ of the \\ total ion peak. Notably, aristolone (20.4\%), benzaldehyde (20.2\%), \\ geranyl acetone $(11.0 \%)$, and 3 -octanone $(10.7 \%)$ were all at higher \\ levels in samples. The main identified compounds were aldehydes, \\ ketones, alcohols, ethers, and alkanes.
}

DOI: 10.15376/biores.17.1.1680-1689

Keywords: SPME-GCMS; Russula rubra (Krombh.) Bres.; Volatile component

Contact information: a: Institute for Forest Resources and Environment of Guizhou/Key Laboratory of Forest Cultivation in Plateau Mountain of Guizhou Province, Guiyang 550025, China; b: College of

Forestry, Guizhou University, Guiyang 550025, China; *Corresponding author: gjdinggzu@126.com

\section{INTRODUCTION}

Pinus massoniana Lamb. is widely planted in southern China and occurs from near sea level to $1,300 \mathrm{~m}$ in elevation (Fig. 1). This pine tree plays a crucial role in China's economy, afforestation, and revegetation projects (Wang et al. 2010). The ecological growth environment of $P$. massoniana is very suitable for the growth of Russula rubra (Krombh.) Bres. (RRKB). $R R \mathrm{~KB}$ is an ectomycorrhizal fungus symbiotic with forest trees (Zhao and Jiang 2014). It has important economic value because it is edible and is used as medicine. As a wild edible fungus, it is rich in nutrition with a delicious taste and has the effects of nourishing the blood and Yin, cooling and detoxifying, lowering cholesterol, protecting the liver, and acting against cancer (Nandi et al. 2013; Stasinska et al. 2016). It is well known that mushrooms have important nutritional value due to their high protein, essential amino acids, fiber content and low-fat content, and are regarded as delicacies due to their texture and taste. People in Chinese folk believe that regular consumption of $R R \mathrm{~KB}$ can enhance immunity, so they stew $R R \mathrm{~KB}$ with meat and use this food to treat human anemia, edema, malnutrition, excessive postpartum hemorrhage, and many other diseases. $R R \mathrm{~KB}$ not only can be used for dishes, but its essential oil can also be used as seasoning. As the main components of the aroma of $R R \mathrm{~KB}$, volatile components are important factors that determine their flavor quality. Among them, the aliphatic eight carbon (C8) components are the main contributors to the unique flavor of $R R K \mathrm{~KB}$. Studies have been conducted on the volatile aroma components of a variety of edible fungi, such as Lentinus edodes (Tian et al. 2016), Flammulina velutipes (Yang et al. 2015), Agaricus bisporus 
(Taskin et al. 2013), and Morchella elata (Skin 2013). The research on the volatile components of $R R \mathrm{~KB}$ has been so lacking that the volatile components of it have not yet been clarified. Volatile component determination has been used for stoichiometric comparisons of strains or species to assess the authenticity of flavoring substances and commercially available food products.

At present, solid-phase microextraction technology is a widely used method for sample preparation. For complex sample processing steps such as extraction, concentration, desorption, and sampling, SPME technology enables these operations to be integrated (Li et al. 2018; Yang et al. 2019). SPME technology has become the preferred technique for sample preparation in food analysis due to its many advantages, such as high sensitivity, simple operation, and low device price (Santos Silva et al. 2019). In this study, solid-phase microextraction-gas chromatography mass spectrometry (SPME-GCMS) technology, which requires only a small number of samples, was able to perform sample pretreatment for headspace adsorption and sample injection for heating and analyzing volatile organic compounds in one step.

The KOVÁTS Retention Index (RI) which was first proposed by Kovats in 1958, represents a behavior of retention value of substances in fixed liquid, and is the most widely used and internationally recognized qualitative index at present (Kováts 1958). The automated mass spectral deconvolution and identification system (AMDIS) can be used to determine the compounds in the samples by comparing with the mass spectral library and extracting the pure mass spectra of each component and relevant information from the mixed material spectral results. In the analysis of natural products, it is very common that the analyte compound encountered is not in the mass spectrum library, and the absence of standards makes it difficult to perform mass spectrometric qualitative analysis. However, it is possible to complete the qualitative analysis of unknown components by using the chromatographic RI, which makes the qualitative and quantitative analysis of complex systems possible in this case. It is difficult to determine the structure of compounds with similar structure and similar retention time by MASS spectrometry when analyzing the sample composition by GC-MS, but the combination of RI and AMDIS method can significantly improve the accuracy of structural determination. The experimental results were accurately characterized by comparing the RI calculated by the actual test with the Kováts RI recorded in the automated mass spectral deconvolution and identification system (AMDIS, U.S. National Institutes of Standards and Technology (NIST)) 2014 edition database.

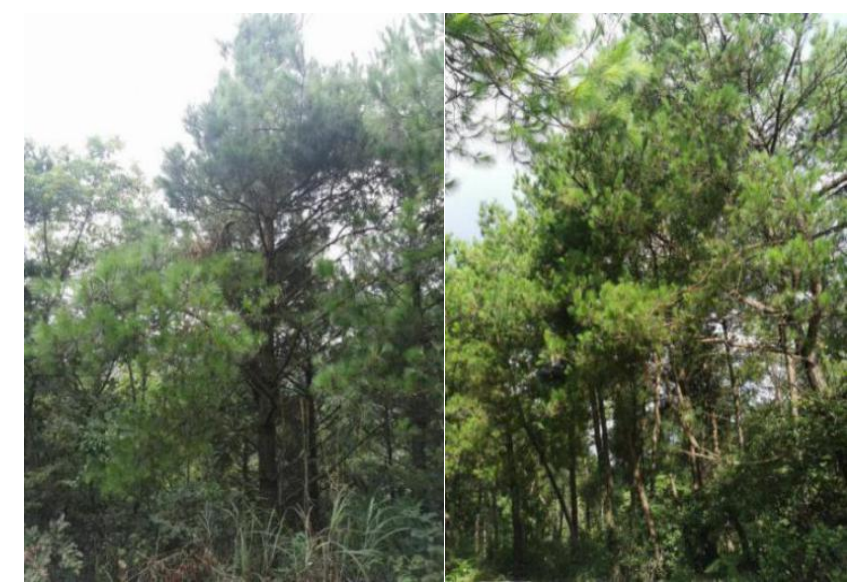

Fig. 1. Pinus massoniana Lamb. forest in Guizhou province. RRKB grows in the soil of Pinus Massoniana Lamb. forest and is symbiotic with the roots of Pinus massoniana Lamb. 
Compared with the traditional method, this method was more accurate in the characterization of compounds. In the current study, the identification of volatile components in $R R \mathrm{~KB}$ essential oil not only provides a reference for the study of $R R \mathrm{~KB}$ oil flavor composition and nutritional value, but it also provides a basis for $R R \mathrm{~KB}$ oil resource development and quality evaluation.

\section{EXPERIMENTAL}

\section{Materials}

Russula rubra (Krombh.) Bres. (RRKB) plants were harvested in Niuchang Town, Baiyun District, Guiyang City, Guizhou Province.

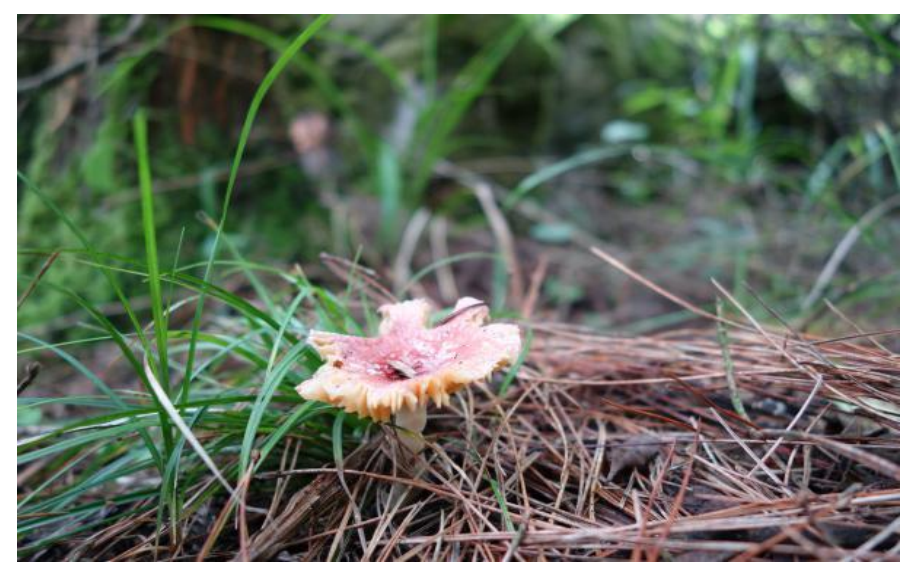

Fig. 2. RRKB growing under Pinus massoniana Lamb. forest

\section{Methods}

For extraction, the whole fresh $R R \mathrm{~KB}$ was taken as a sample and cut into cubes of about $3 \mathrm{~mm}$. Then $5 \mathrm{~g}$ of an $R R \mathrm{~KB}$ specimen was placed in an SPME sample bottle. Next, $2 \mu \mathrm{L}$ of cyclohexanone with a concentration of $1.54 \mu \mathrm{g} / \mathrm{mL}$ was added to the SPME sample bottle, and the bottle was then immediately sealed after being placed in an agitator. The manual injector for a $2 \mathrm{~cm}-50 / 30 \mathrm{~m}$ DVB/CAR/PDMS StableFlex fiber head was mounted on the sample bottle. Samples were magnetically stirred during extraction at $60{ }^{\circ} \mathrm{C}$ for 55 min. Finally, the fiber head, which was removed and placed into the gas chromatograph inlet, underwent thermal analysis.

\section{Chromatography}

Gas chromatography (GC) conditions

The samples were tested and analyzed using a HP6890/5975C Gas Phase Mass Spectrometer (Agilent Technologies, Santa Clara, USA). An HP-5MS capillary column $(60 \mathrm{~m} \times 0.25 \mathrm{~mm} \times 0.25 \mu \mathrm{m})$ was used. The column temperature was gradually increased for $60 \mathrm{~min}$ after the sample was injected. After the initial column temperature was maintained at $40{ }^{\circ} \mathrm{C}$ for $2 \mathrm{~min}$, the column temperature increased to $208^{\circ} \mathrm{C}$ at a rate of $3.5^{\circ} \mathrm{C} / \mathrm{min}$, and finally to $308{ }^{\circ} \mathrm{C} / \mathrm{min}$ at a rate of $10{ }^{\circ} \mathrm{C} / \mathrm{min}$. The column temperature was maintained at $40{ }^{\circ} \mathrm{C}$ for $2 \mathrm{~min}$, then heated at $2{ }^{\circ} \mathrm{C} / \mathrm{min}$ to $120{ }^{\circ} \mathrm{C}$, and finally heated at $10{ }^{\circ} \mathrm{C} / \mathrm{min}$ to 310 ${ }^{\circ} \mathrm{C}$ for $1 \mathrm{~min}$. The total running time was $62 \mathrm{~min}$. The vaporization chamber temperature 
was $250{ }^{\circ} \mathrm{C}$, and the pressure in front of the column was $110.04 \mathrm{kPa}$. The carrier gas was high purity $\mathrm{He}(99.999 \%)$ with a flow rate of $1.0 \mathrm{~mL} / \mathrm{min}$. No separate injection was required. The solvent delay time was $3 \mathrm{~min}$.

\section{Mass spectrometry (MS) conditions}

The transmitted impact (EI) ion source was used to detect samples. The temperature of the EI ion source was $230^{\circ} \mathrm{C}$, and the quadrupole temperature was $150{ }^{\circ} \mathrm{C}$. The electron energy was $70 \mathrm{eV}$, the emission current was $34.6 \mu \mathrm{A}$, and the multiplier voltage was 1517 $\mathrm{V}$. The interface temperature was $280{ }^{\circ} \mathrm{C}$, and the mass range of scanning ion fragments was 29 to $500 \mathrm{u}$.

\section{Statistical Analysis}

The compounds were identified by searching and verifying the NIST17 and Wiley275 standard mass spectra and mass spectrometry computer data system for each peak in the total ion flow chart. The relative mass fraction of the chemical composition was determined by the peak area normalization method.

\section{RESULTS AND DISCUSSION}

\section{Data Acquisition}

After injection using SPME technology, the sample was separated into compounds by a gas chromatographic column. The molecular fragment data were recorded by the mass spectrometry software. The total ion chromatogram of the experimental results is shown in Fig. 3.

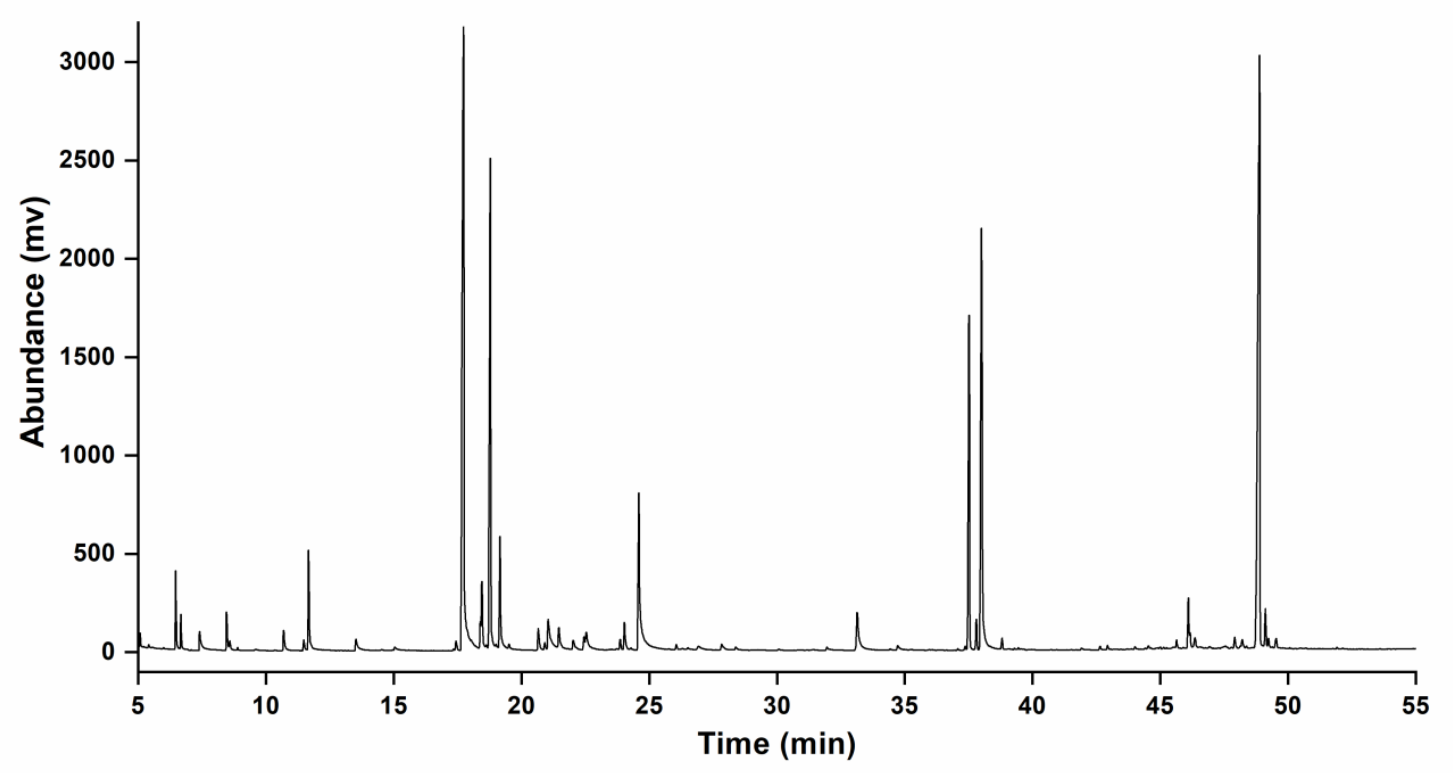

Fig. 3. GC-MS total ion chromatogram of volatile compounds in $R R K B$

\section{Data Analysis}

The corresponding MS spectra were obtained by MS scanning of the peaks in the total ion flow diagram. The NIST 14 and Wiley275 standard mass spectrometer data 
system in the Chem Station were used to retrieve the relevant mass spectrometer information combined with MS Search V. 2.2 software.

NIST 14 contained MS Search V. 2.2, AMDIS Version 2.72, MS Interpreter, and MS Search software, which could be integrated into Chem Station or run independently. AMDIS could extract a single mass spectrogram and associated chromatographic information for each component from the data obtained by GC/MS or liquid chromatography/mass spectrometry (LC/MS) analysis of the mixture. This information was used to determine whether the component could be identified as a compound in the reference database.

It was difficult to determine compounds only by mass spectrometry fragment ion and abundance ratio. Compounds with similar initial structures, such as isomers and homologues, were prone to misjudgment according to their matching degree. In order to more accurately identify the target compound and obtain more reliable results, a combination of three methods was used for the qualitative analysis that included mass spectrometry database, AMDIS, and RI. Combining chromatographic analysis with mass spectrometry could improve the accuracy of the determination of volatile components in $R R \mathrm{~KB}$. First, the combination improved the ability to resolve overlapping peaks in the GCMS results by using AMDIS to deconvolve the GC-MS results to remove background noise and eliminate the overlapping components of the results. Then, the chemical composition of the volatile oil could be determined more accurately by comparing the different RI with the mass spectrum library.

Under the same experimental conditions, the MS data for the n-alkane mixture standard of $\mathrm{C}_{8}-\mathrm{C}_{20}$ were analyzed to calculate the RI (Fig. 4). The RI for each component was calculated by using the linear heating formula, which was calculated as follows (Van den Dool and Kratz 1963),

$$
R I=100 n+100(N-n) \times\left(t_{x}-t_{n}\right) /\left(t_{n+1}-t_{n}\right)
$$

where $t_{\mathrm{x}}, t_{\mathrm{n}}$, and $t_{\mathrm{n}+1}$ are respectively the retention times of $\mathrm{n}$-alkanes with the analyzed components and the number of carbon atoms of $n$ and $n+1 . N$ and $n$ represent the number of carbon atoms of two n-alkanes, and the difference between $N$ and $n$ is generally 1 .

The amount of each compound was calculated by the ratio of the peak area of the internal standard compound to the sealing area of each compound. They are arranged in the order of retention of the peak of the compound, and the compound information and percentage are shown in Table 1. In this study, 52 volatile components were identified from $R R K B$ essential oil, including aldehydes, alcohols, ketones, ethers, and other compounds. The relative percentage of volatile components accounted for $85.4 \%$ of the total ion peak. The proportions of each component are shown in Fig. 5.

Volatile components with a relative content of greater than $10.0 \%$ in $R R \mathrm{~KB}$ were benzaldehyde (20.3\%), aristolone (20.4\%), 3-octanone (10.7\%), and geranyl acetone (11.0\%). C8 as the substantial base of mushroom volatile components contained up to $21.1 \%$ in Russula. It was worth noting that RRKB contained 1-octanol, 3-octanol, 3-octanone, 1octen-3-ol, 2-octen-1-ol, 1-octen-3-one and other characteristic compounds with mushroom flavor. Among them, the relative content of 3 -octanone was the highest $10.7 \%$, which was the main volatile component that affects the flavor of $R R \mathrm{~KB}$. The reason for the sweet taste and tender texture of $R R \mathrm{~KB}$ may be related to the content of benzaldehyde and geranyl acetone as high as $20.3 \%$ and $11.0 \%$, respectively. Other studies had found that benzaldehyde was the main ingredient that causes the stronger caramel-like flavor in mushrooms (Liu et al. 2003) and its content was related to the texture of mushrooms which 
had a significant impact on it (Nosaka and Miyazawa 2014). Geranyl acetone were significantly and positively correlated to mushroom-like flavor (Chen et al. 2018). The content of copper aristolochia that had obvious antioxidant and cancer-killing activities (Priya and Padmakumari 2012; Memariani et al. 2016; Anjum et al. 2019) in the volatile components of $R R \mathrm{~KB}$, was as high as $20.4 \%$, which provides certain theoretical support for it as a natural product for medicine and food.

Table 1. The Volatile Component of RRKB Essential Oil

\begin{tabular}{|c|c|c|c|c|c|c|}
\hline NO. & $\begin{array}{l}\text { Retention } \\
\text { Time (Min) }\end{array}$ & Compound & $\begin{array}{c}\text { Molecular } \\
\text { Formula }\end{array}$ & $\begin{array}{l}\text { Molecular } \\
\text { Weight }\end{array}$ & $\begin{array}{c}\mathrm{RI} \\
(\mathrm{NIST} 14)\end{array}$ & $\begin{array}{c}\text { Percentage } \\
\text { Composition } \\
(\%)\end{array}$ \\
\hline 1 & 4.2 & Acetaldehyde & $\mathrm{C}_{2} \mathrm{H}_{4} \mathrm{O}$ & 44 & 404 & 0.4 \\
\hline 2 & 4.4 & Ethanol & $\mathrm{C}_{2} \mathrm{H}_{6} \mathrm{O}$ & 46 & 427 & 0.5 \\
\hline 3 & 4.6 & Acetone & $\mathrm{C}_{3} \mathrm{H}_{6} \mathrm{O}$ & 58 & 486 & 0.2 \\
\hline 4 & 5.1 & Isobutanal & $\mathrm{C}_{4} \mathrm{H}_{8} \mathrm{O}$ & 72 & 552 & 0.2 \\
\hline 5 & 5.2 & Methacrolein & $\mathrm{C}_{4} \mathrm{H}_{6} \mathrm{O}$ & 70 & 567 & $9.0 \times 10^{-3}$ \\
\hline 6 & 5.4 & 2,3-Butanedione & $\mathrm{C}_{4} \mathrm{H}_{6} \mathrm{O}_{2}$ & 86 & 595 & $5.0 \times 10^{-2}$ \\
\hline 7 & 5.6 & 2-Butanone & $\mathrm{C}_{4} \mathrm{H}_{8} \mathrm{O}$ & 72 & 598 & $2.0 \times 10^{-2}$ \\
\hline 8 & 6.0 & 2-Methylpropanol & $\mathrm{C}_{4} \mathrm{H}_{10} \mathrm{O}$ & 74 & 625 & $2.6 \times 10^{-2}$ \\
\hline 9 & 6.5 & 3-Methylbutanal & $\mathrm{C}_{5} \mathrm{H}_{10} \mathrm{O}$ & 86 & 652 & 1.1 \\
\hline 10 & 6.7 & 2-Methylbutanal & $\mathrm{C}_{5} \mathrm{H}_{10} \mathrm{O}$ & 86 & 662 & 0.5 \\
\hline 11 & 7.1 & 3-Methyl-2-butanol & $\mathrm{C}_{5} \mathrm{H}_{12} \mathrm{O}$ & 88 & 674 & $1.0 \times 10^{-1}$ \\
\hline 12 & 8.5 & 3-Methylbutanol & $\mathrm{C}_{5} \mathrm{H}_{12} \mathrm{O}$ & 88 & 736 & 0.7 \\
\hline 13 & 8.6 & 2-Methylbutanol & $\mathrm{C}_{5} \mathrm{H}_{12} \mathrm{O}$ & 88 & 739 & 0.2 \\
\hline 14 & 8.9 & 2-Methylpentanal & $\mathrm{C}_{6} \mathrm{H}_{12} \mathrm{O}$ & 100 & 759 & $5.2 \times 10^{-2}$ \\
\hline 15 & 10.7 & Hexanal & $\mathrm{C}_{6} \mathrm{H}_{12} \mathrm{O}$ & 100 & 800 & 0.5 \\
\hline 16 & 11.7 & 1,3-Octadiene & $\mathrm{C}_{8} \mathrm{H}_{14}$ & 110 & 827 & 2.1 \\
\hline 17 & 13.5 & 1-Hexanol & $\mathrm{C}_{6} \mathrm{H}_{14} \mathrm{O}$ & 102 & 868 & 0.5 \\
\hline 18 & 14.5 & 2-Heptanone & $\mathrm{C}_{7} \mathrm{H}_{14} \mathrm{O}$ & 114 & 891 & $2.0 \times 10^{-2}$ \\
\hline 19 & 15.0 & Heptanal & $\mathrm{C}_{7} \mathrm{H}_{14} \mathrm{O}$ & 114 & 901 & $1.7 \times 10^{-2}$ \\
\hline 20 & 17.4 & (E)-2-Heptenal & $\mathrm{C}_{7} \mathrm{H}_{12} \mathrm{O}$ & 112 & 958 & 0.2 \\
\hline 21 & 17.7 & Benzaldehyde & $\mathrm{C}_{7} \mathrm{H}_{6} \mathrm{O}$ & 106 & 962 & 20.2 \\
\hline 22 & 18.1 & 1-Heptanol & $\mathrm{C}_{7} \mathrm{H}_{16} \mathrm{O}$ & 116 & 970 & 0.2 \\
\hline 23 & 18.4 & 1-Octen-3-one & $\mathrm{C}_{8} \mathrm{H}_{14} \mathrm{O}$ & 126 & 979 & 0.3 \\
\hline 24 & 18.4 & 1-Octen-3-ol & $\mathrm{C}_{8} \mathrm{H}_{16} \mathrm{O}$ & 128 & 980 & 1.4 \\
\hline 25 & 18.8 & 3-Octanone & $\mathrm{C}_{8} \mathrm{H}_{16} \mathrm{O}$ & 128 & 986 & 10.7 \\
\hline 26 & 19.0 & 2-Amylfuran & $\mathrm{C}_{9} \mathrm{H}_{14} \mathrm{O}$ & 138 & 993 & $5.0 \times 10^{-2}$ \\
\hline 27 & 19.2 & 3-Octanol & $\mathrm{C}_{8} \mathrm{H}_{18} \mathrm{O}$ & 130 & 994 & 2.4 \\
\hline 28 & 19.5 & Octanal & $\mathrm{C}_{8} \mathrm{H}_{16} \mathrm{O}$ & 128 & 1003 & 0.1 \\
\hline 29 & 20.7 & 2-Ethylhexanol & $\mathrm{C}_{8} \mathrm{H}_{18} \mathrm{O}$ & 130 & 1030 & 0.5 \\
\hline 30 & 20.9 & $\begin{array}{c}\text { 3-Ethyl-2-methyl-1,3- } \\
\text { hexadiene }\end{array}$ & $\mathrm{C}_{9} \mathrm{H}_{16}$ & 124 & 1031 & 0.2 \\
\hline 31 & 21.0 & Benzyl alcohol & $\mathrm{C}_{7} \mathrm{H}_{8} \mathrm{O}$ & 108 & 1036 & 1.5 \\
\hline 32 & 21.5 & $\begin{array}{c}\text { Benzeneacetaldehyd } \\
\text { e }\end{array}$ & $\mathrm{C}_{8} \mathrm{H}_{8} \mathrm{O}$ & 120 & 1045 & 0.6 \\
\hline 33 & 22.0 & (E)-2-Octenal & $\mathrm{C}_{8} \mathrm{H}_{14} \mathrm{O}$ & 126 & 1060 & 0.4 \\
\hline 34 & 22.4 & (E)-2-Octenol & $\mathrm{C}_{8} \mathrm{H}_{16} \mathrm{O}$ & 128 & 1067 & 0.3 \\
\hline 35 & 22.5 & 1-Octanol & $\mathrm{C}_{8} \mathrm{H}_{18} \mathrm{O}$ & 130 & 1071 & 0.8 \\
\hline 36 & 23.9 & Linalool & $\mathrm{C}_{10} \mathrm{H}_{18} \mathrm{O}$ & 154 & 1099 & 0.2 \\
\hline 37 & 24.0 & Nonanal & $\mathrm{C}_{9} \mathrm{H}_{18} \mathrm{O}$ & 142 & 1104 & 0.7 \\
\hline 38 & 24.6 & Phenylethyl Alcohol & $\mathrm{C}_{8} \mathrm{H}_{10} \mathrm{O}$ & 122 & 1116 & 5.5 \\
\hline 39 & 26.9 & $\begin{array}{c}\mathrm{m}- \\
\text { Dimethoxybenzene }\end{array}$ & $\mathrm{C}_{8} \mathrm{H}_{10} \mathrm{O}_{2}$ & 138 & 1166 & 0.3 \\
\hline 40 & 27.8 & 2-Decanone & $\mathrm{C}_{10} \mathrm{H}_{20} \mathrm{O}$ & 156 & 1193 & 0.1 \\
\hline
\end{tabular}




\begin{tabular}{|c|c|c|c|c|c|c|}
\hline 41 & 28.4 & Decanal & $\mathrm{C}_{10} \mathrm{H}_{20} \mathrm{O}$ & 156 & 1206 & 0.1 \\
\hline 42 & 31.4 & 2-Phenyl-2-butenal & $\mathrm{C}_{10} \mathrm{H}_{10} \mathrm{O}$ & 146 & 1279 & $4.9 \times 10^{-2}$ \\
\hline 43 & 31.9 & 2-Undecanone & $\mathrm{C}_{11} \mathrm{H}_{22} \mathrm{O}$ & 170 & 1294 & 0.2 \\
\hline 44 & 34.7 & 2-Undecenal & $\mathrm{C}_{11} \mathrm{H}_{20} \mathrm{O}$ & 168 & 1367 & 0.2 \\
\hline 45 & 38.0 & Geranyl acetone & $\mathrm{C}_{13} \mathrm{H}_{22} \mathrm{O}$ & 194 & 1453 & 11.0 \\
\hline 46 & 41.9 & Nerolidol & $\mathrm{C}_{15} \mathrm{H}_{26} \mathrm{O}$ & 222 & 1544 & $6.4 \times 10^{-2}$ \\
\hline 47 & 42.9 & Hexadecane & $\mathrm{C}_{16} \mathrm{H}_{34}$ & 226 & 1600 & $9.0 \times 10^{-2}$ \\
\hline 48 & 45.6 & a-Costal & $\mathrm{C}_{15} \mathrm{H}_{22} \mathrm{O}$ & 218 & 1695 & 0.2 \\
\hline 49 & 46.2 & Heptadecane & $\mathrm{C}_{17} \mathrm{H}_{36}$ & 240 & - & 0.3 \\
\hline 50 & 48.9 & Aristolone & $\mathrm{C}_{15} \mathrm{H}_{22} \mathrm{O}$ & 218 & 1762 & 20.4 \\
\hline 51 & 49.2 & Octadecane & $\mathrm{C}_{18} \mathrm{H}_{38}$ & 254 & 1800 & 0.2 \\
\hline 52 & 51.9 & Nonadecane & $\mathrm{C}_{19} \mathrm{H}_{40}$ & 268 & 1900 & $4.0 \times 10^{-2}$ \\
\hline
\end{tabular}

Note:"-" Indicates that this value is not recorded in the NIST14 database

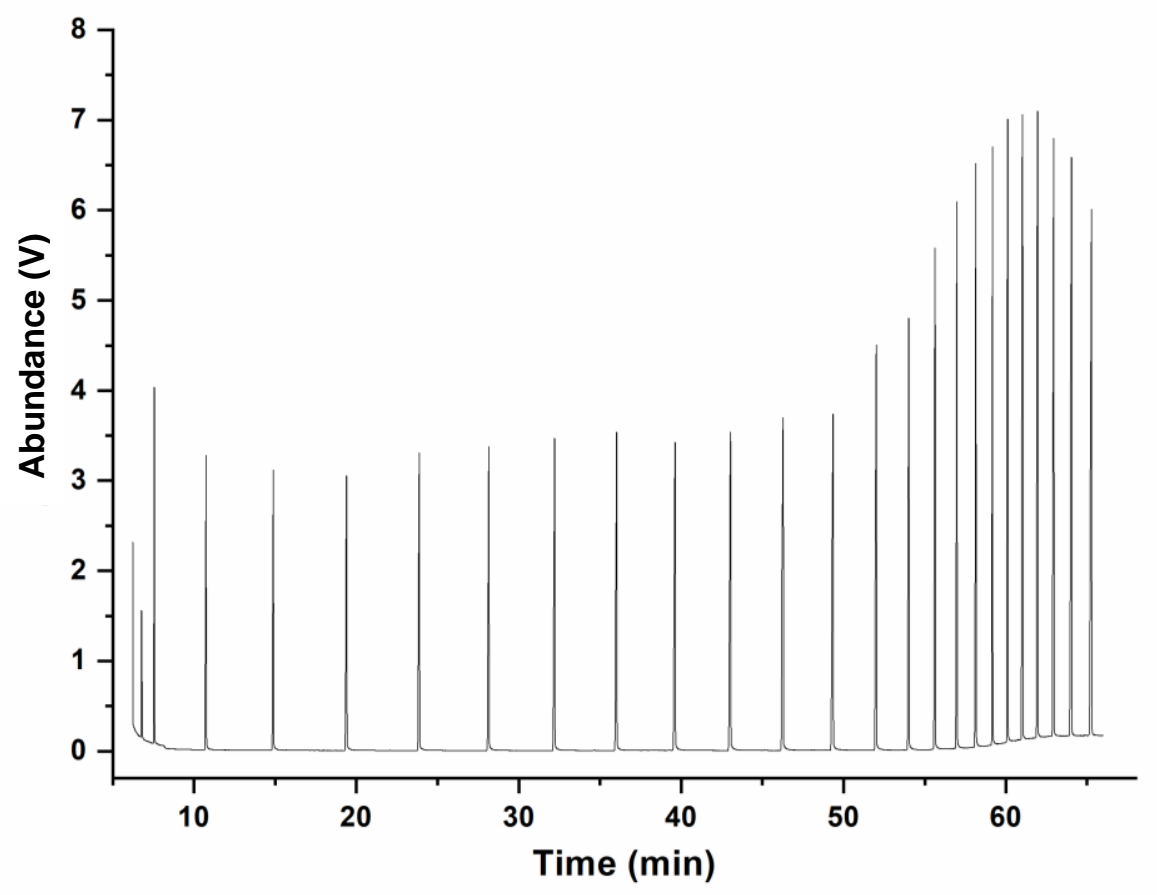

Fig. 4. TIC diagram of total ion flow of $\mathrm{C}_{7}-\mathrm{C}_{20}$ normal alkane mixture control substance 


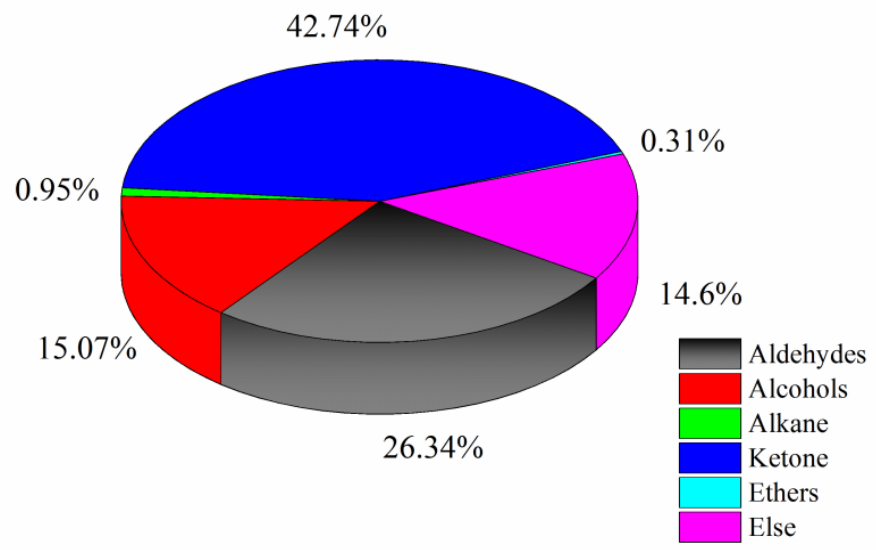

Fig. 5. Percentage graph of various compounds

\section{CONCLUSIONS}

1. As a means to overcome the qualitative problems of common overlapping peaks, shoulder peaks, and low signal-to-noise ratio peaks in mass spectra by automated mass spectral deconvolution and identification system (AMDIS) and identifying similar homologues and isomers in the mass spectra by Kováts retention index (RI), the method of combining AMDIS with IR was used to analysed the GC-MS of volatile components from $R R \mathrm{~KB}$, and 52 compounds were successfully obtained.

2. The data showed that the volatile organic compounds in $R R \mathrm{~KB}$ essential oil were mainly ketones $(42.7 \%)$, aldehydes $(26.3 \%)$, alcohols $(15.1 \%)$, alkanes $(0.9 \%)$, and ethers $(0.3 \%)$. Compared with other studies, it was found that $R R \mathrm{~KB}$ not only had the unique flavor of mushrooms, but also had the characteristics of freshness, sweetness, and tenderness because of benzaldehyde (20.2\%), Aristolone (20.4\%), 3-Octanone $(10.7 \%)$, and Geranyl acetone $(11.0 \%)$ were the main volatile components in $R R \mathrm{~KB}$. In addition, the volatile components obtained in this study could be used as the basis for the identification of wild $R R \mathrm{~KB}$ and provided a theoretical basis for the formation mechanism of flavor substances in $R R \mathrm{~KB}$.

\section{ACKNOWLEDGEMENTS}

This study was financially supported by the National Key Research and Development Program of China (No.2017YFD0600302), the National Natural Science Foundation of China (No. 31660200), the Science and Technology Planning Project of Guizhou Province (QKHPTRC [2018]5261). 


\section{REFERENCES CITED}

Anjum, B., Ravendra, K., Kumar, R., Prakash, O., Srivastava, R. M., and Pant, A. K. (2019). "Phytochemical analysis, antioxidant, anti-inflammatory and insect antifeeding activity of Ardisia solanacea Roxb. Extracts," Journal of Biologically Active Products from Nature 9(5), 372-386. DOI: 10.1080/22311866.2019.1702899

Chen, X., Yu, J. Y., Cui, H. P., and Xia, S. Q. (2018). "Effect of temperature on flavor compounds and sensory characteristics of maillard reaction products derived from mushroom hydrolysate," Molecules 23, 247. DOI: 10.3390/molecules23020247.

Kováts, E. (1958). "Gas-chromatographische Charakterisierung organischer Verbindungen. Teil 1: Retentionsindices aliphatischer Halogenide, Alkohole, Aldehyde und Ketone," Helvetica Chimica Acta 41(7), 1915-1932. DOI: 10.1002/hlca.19580410703

Li, J., Zhang, Z., Sun, M., Zhang, B., and Fan, C. (2018). "Use of a headspace solidphase microextraction-based methodology followed by gas chromatography-tandem mass spectrometry for pesticide multiresidue determination in teas," Chromatographia 81(5), 809-821. DOI: 10.1007/s10337-018-3499-z

Liu, J. H., Vijayakumar, C., Hall, C. A., Hadley, M., and Wolf Hall, C. E. (2005). "Sensory and chemical analyses of oyster mushrooms (Pleurotus sajor-caju) harvested from different substrates," Journal of Food Science 70(9), S586-S592. DOI: $10.1111 / \mathrm{j} .1365-2621.2005 . t b 08333 . x$

Memariani, T., Hosseini, T., Kamali, H., Mohammadi, A., Ghorbani, M., Shakeri, A., Spandidos, D. A., Tsatsakis, A. M., and Shahsacand, S. (2016). "Evaluation of the cytotoxic effects of Cyperus longus extract, fractions and its essential oil on the PC3 and MCF7 cancer cell lines," Oncology Letters. 11, 1353-1360. DOI: $10.3892 / \mathrm{ol} .2015 .4050$

Nandi, A. K., Samanta, S., Sen, I. K., Devi, K. S. P., Maiti, T. K., Acharya, K., and Islam, S. S. (2013). "Structural elucidation of an immunoenhancing heteroglycan isolated from Russula albonigra (Krombh.) Fr.," Carbohydrate Polymers 94(2), 918-926. DOI: 10.1016/j.carbpol.2013.02.019

Nosaka, S., and Miyazawa, M. (2014). "Characterization of volatile components and odor-active compounds in the oil of edible mushroom Boletopsis leucomelas," Journal of Oleo Science 63(6), 577. DOI: 10.5650/jos.ess 13215

Priya, M., and Padmakumari, K. P. (2012). "HPTLC and reverse phase HPLC methods for the simultaneous quantification and in vitro screening of antioxidant potential of isolated sesquiterpenoids from the rhizomes of Cyperus rotundus," Journal of Chromatography B 904(1), 22-28. DOI: 10.1016/j.jchromb. 2012.05 .042

Santos Silva, J., Damiani, C., da Cunha, M. C., Nunes Carvalho, E. E., and de Barros Vilas Boas, E. V. (2019). "Volatile profiling of pitanga fruit (Eugenia uniflora L.) at different ripening stages using solid-phase microextraction and mass spectrometry coupled with gas chromatography," Scientia Horticulturae 250, 366-370. DOI: 10.1016/j.scienta.2019.02.076

Skin, H. T. (2013). "Detection of volatile aroma compounds of morchella by headspace gas chromatography mass spectrometry (HS-GC/MS)," Notulae Botanicae Horti Agrobotanici Cluj-Napoca 41(1), 122-125. DOI: 10.15835/nbha4118344

Stasinska, M., Sotek, Z., Ruszkiewicz-M., M., and Bialecka, B. (2016). "Russula torulosa (Basidiomycota: Russulales) a new record to Poland," Nova Hedwigia 103(1-2), 145154. DOI: $10.1127 /$ nova_hedwigia/2016/0341 
Taskin, H., Kafkas, E., and Saadet, B. (2013). "Comparison of various extraction conditions in Agaricus bisporus by gas chromatography mass spectrometry (HSGC/MS) technique" Journal of Food Agriculture and Environment 11(2), 97-99. DOI: $10.1234 / 4.2013 .4198$

Tian, Y.T., Zhao, Y. T., Huang, J. J., Zeng, H. L., and Zheng, B. D. (2016). "Effects of different drying methods on the product quality and volatile compounds of whole shiitake mushrooms," Food Chemistry 197, 714-722. DOI: 10.1016/j.foodchem.2015.11.029

Van den Dool, H., and Kratz, P. D. (1963). "A generalization of the retention index system including linear temperature programmed gas-liquid partition chromatography," Journal of Chromatography A 20(11), 463. DOI: 10.1016/S00219673(01)80947-X

Wang, C., Guo P., Han, G., Feng, X. G., Zhang, P., and Tian, X. J. (2010). "Effect of simulated acid rain on the litter decomposition of Quercus acutissima and Pinus massoniana in forest soil microcosms and the relationship with soil enzyme activities," Science of the Total Environment 408(13), 2706-2713. DOI: 10.1016/j.scitotenv.2010.03.023

Yang, W. j., Yu, J., Pei, F., Mariga, M., Ma, N., Fang, Y., and Hu, Q. H. (2015). "Effect of hot air drying on volatile compounds of Flammulina velutipes detected by HSSPME-GC-MS and electronic nose," Food Chemistry 196(1), 860-866. DOI: 10.1016/j.foodchem.2015.09.097

Yang, Y., Mai, W., Gao, J., Hu, Z., Xu, J. Q., and Zou, S. C. (2019). “An in-needle solidphase microextraction device packed with etched steel wires for polycyclic aromatic hydrocarbons enrichment in water samples," Journal of Separation Science 49(2), 1750-1756. DOI: 10.1002/jssc. 201801112

Zhao, G., and Jiang, X. (2014). "Roles of gibberellin and auxin in promoting seed germination and seedling vigor in Pinus massoniana," Forest Science 60(2), 367-373. DOI: 10.5849/forsci.12-143

Article submitted: October 11, 2021; Peer review completed: November 6, 2021; Revised version received and accepted: December 27, 2021; Published: January 20, 2022.

DOI: $10.15376 /$ biores.17.1.1680-1689 